\title{
Thalassaemia in Scots
}

\author{
K. D. BUCHANAN, J. D. KINLOCH, ${ }^{1}$ H. E. HUTCHISON, \\ P. H. PINKERTON, AND PATRICIA CASSIDY
}

From the Glasgow Royal Infirmary and the University Department of Haematology, Western Infirmary, Glasgow

SYNOPSIS Five cases of thalassaemia minor and 11 symptomless trait carriers have been detected in four Scottish families, only one of which is known to have foreign ancestry. It is suggested that the $\vec{\sigma}$ condition is commoner than was once thought, and that the diagnosis should be considered in any $i \circ$ patient with refractory hypochromic anaemia in which the red cells show increased osmotic resis- $\mathscr{Q}$ tance.

In recent years there has been an increased awareness of the widespread distribution of thalassaemia, and the first British case, the mother of a Scottish family from Dundee, which had emigrated to Canada, was described by L. G. Israëls, Suderman, and Hoogstraten (1955); three other members were also affected.

Shortly afterwards, M. C. G. Israëls and Turner (1955) reported two English families with several members affected. More recently, a larger series has been described by Callender, Mallet, and Lehmann. (1961) who found heterozygotes in three English families. Other isolated examples in presumed British stock have been described by Havard, Lehmann, and Scott (1958), McFarland and Pearson (1960), Vella and Ibrahim (1961), and Josse (1962).

Our purpose is to record the presence of five cases of thalassaemia minor and 11 symptomless carriers of the trait in four Scottish families and to draw further attention to the desirability of considering this diagnosis in refractory hypochromic anaemia, especially when the red cells show increased osmotic resistance.

\section{METHODS}

Standard haematological investigations were performed by the methods described by Dacie (1956). Red cell survival was assessed by radioactive chromium studies (Mollison and Veall, 1955); normal $\mathrm{T}_{2}^{151} \mathrm{Cr}-20-26$ days. Haemoglobin $\mathrm{A}_{2}$ concentrations were determined by the method of Hutchison, Pinkerton, Cassidy, and Aiton (1963), which gives a mean normal value of $2 \%$ (S.D. 0.56). In a few cases the method of Singer, Chernoff, and

\footnotetext{
1Present address: Western General Hospital, Edinburgh.
}

Received for publication 26 April 1963
Singer (1951) was used to estimate haemoglobin F. Values by this method are recorded down to $2 \%$; below this as 'less than $2 \%$ '. In the main, however, the more $\stackrel{\mathbb{1}}{-}$ accurate modification of Singer's method described by Went and McIver (1961) has been used, allowing estima- $\mathscr{\odot}$ tions down to a concentration of $1 \%$; below this they are recorded as 'less than $1 \%$ ' (see Table).

\section{CASE REPORTS}

CASE 1 C.R., a woman 22 years old, presented in

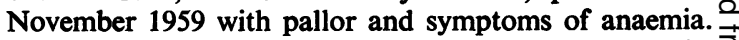
The blood findings are recorded in the Table and the $\overline{0}$ appearances of the red cells are shown in Figure I. Red cell survival was normal $\left(\mathrm{T} \frac{1}{2}\right.$ of ${ }^{51} \mathrm{Cr}=25$ days).

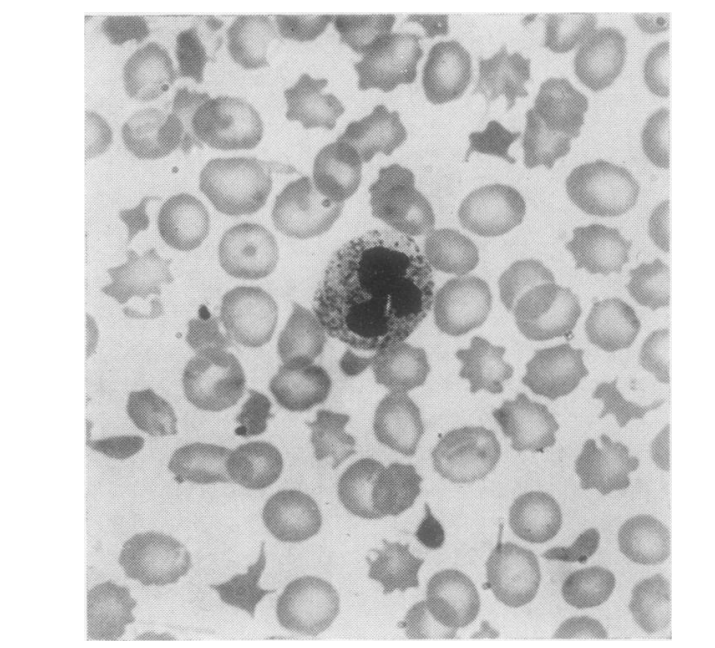

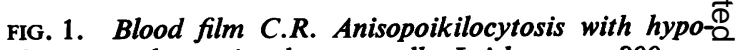
chromia and occasional target cells. Leishman $\times 800$. 
TABLE OF HAEMATOLOGICAL FINDINGS

\begin{tabular}{|c|c|c|c|c|c|c|c|c|c|c|c|}
\hline \multirow[t]{2}{*}{ Reference } & \multirow{2}{*}{$\begin{array}{l}\mathrm{Hb} \\
(\mathrm{g} . / 100 \mathrm{ml} .)\end{array}$} & \multirow{2}{*}{$\begin{array}{l}\text { Reticulocytes } \\
(\%)\end{array}$} & \multirow{2}{*}{$\begin{array}{l}\text { M.C.H.C. } \\
(\%)\end{array}$} & \multirow{2}{*}{$\begin{array}{l}\text { Target } \\
\text { Cells }\end{array}$} & \multirow{2}{*}{$\begin{array}{l}\text { Mean } \\
\text { Corpuscular } \\
\text { Fragility } \\
(\% \mathrm{NaCl})\end{array}$} & \multirow{2}{*}{$\begin{array}{l}\text { Serum } \\
\text { Iron } \\
\text { ( } \mu \mathrm{g} .1100 \mathrm{ml} .\end{array}$} & \multicolumn{3}{|l|}{ Marrow } & \multirow{2}{*}{$\begin{array}{l}\boldsymbol{H b F} \\
-(\%)\end{array}$} & \multirow{2}{*}{$\begin{array}{l}H b A_{2} \\
(\%)\end{array}$} \\
\hline & & & & & & & Iron & P.A.S. & Sideroblasts & & \\
\hline $\begin{array}{l}\text { C.R. (case 1) } \\
\text { E.McC. (case 2) } \\
\text { C.McE. } \\
\text { M.O'H. }\end{array}$ & $\begin{array}{l}10 \cdot 9 \\
11 \cdot 0 \\
11 \cdot 1 \\
10 \cdot 2\end{array}$ & $\begin{array}{c}1.8 \\
1.8-6.8 \\
1.0 \\
1.4\end{array}$ & $\begin{array}{l}32 \\
29 \\
31 \\
30\end{array}$ & $\begin{array}{l}+ \\
+ \\
+ \\
+\end{array}$ & $\begin{array}{l}0.315 \\
0.34 \\
0.365 \\
0.355\end{array}$ & $\begin{array}{r}44 \\
125 \\
90 \\
85\end{array}$ & $\begin{array}{c}\text { Absent } \\
\text { Present } \\
- \\
-\end{array}$ & $\begin{array}{c}\text { Negative } \\
- \\
-\end{array}$ & $\begin{array}{c}\text { Occasional } \\
- \\
-\end{array}$ & $\begin{array}{l}1 \cdot 2 \\
1.9 \\
1 \cdot 2 \\
2 \cdot 5\end{array}$ & $\begin{array}{l}6 \cdot 2 \\
7 \cdot 4 \\
4 \cdot 6 \\
4 \cdot 8\end{array}$ \\
\hline $\begin{array}{l}\text { J.G. (case 3) } \\
\text { J.J. } \\
\text { E.J. } \\
\text { J.J. }\end{array}$ & $\begin{array}{r}8 \cdot 6 \\
11 \cdot 2 \\
11 \cdot 6 \\
12 \cdot 8\end{array}$ & $\begin{array}{l}1 \cdot 3 \\
1 \cdot 4 \\
-\end{array}$ & $\begin{array}{l}29 \\
30 \\
29 \\
30\end{array}$ & $\begin{array}{l}+ \\
+ \\
+\end{array}$ & $\begin{array}{l}0.34 \\
0.355 \\
0.34 \\
0.365\end{array}$ & $\begin{array}{r}123 \\
50 \\
- \\
-\end{array}$ & $\begin{array}{c}\text { Present } \\
\text { Present } \\
- \\
-\end{array}$ & $\begin{array}{c}\text { - } \\
\text { Negative } \\
- \\
-\end{array}$ & $\begin{array}{c}\text { Occasional } \\
\text { - }\end{array}$ & $\begin{array}{l}<2 \\
<2 \\
<2 \\
<2\end{array}$ & $\begin{array}{l}4 \cdot 4 \\
5 \cdot 8 \\
6 \cdot 6 \\
6 \cdot 2\end{array}$ \\
\hline $\begin{array}{l}\text { M.McT. (case 4) } \\
\text { M.N. } \\
\text { R.K. } \\
\text { M.A. }\end{array}$ & $\begin{array}{r}9 \cdot 2 \\
11 \cdot 2 \\
12 \cdot 9 \\
12 \cdot 1\end{array}$ & $\begin{array}{l}2.0 \\
1.0 \\
3.0 \\
-\end{array}$ & $\begin{array}{l}29 \\
32 \\
29 \\
30\end{array}$ & $\begin{array}{l}- \\
- \\
-\end{array}$ & $\begin{array}{l}0.37 \\
0 \cdot 365 \\
0 \cdot 385 \\
-\end{array}$ & $\frac{65}{-}$ & $\begin{array}{c}\text { Present } \\
- \\
-\end{array}$ & $\begin{array}{c}\text { Negative } \\
\text { - } \\
\text { - }\end{array}$ & $\begin{array}{c}\text { Occasional } \\
\text { - } \\
-\end{array}$ & $\begin{array}{l}6 \cdot 6 \\
<1 \\
3 \cdot 5 \\
-\end{array}$ & $\begin{array}{c}5 \cdot 2 \\
4 \cdot 1 \\
4 \cdot 5 \\
\text { 3-fold } \\
\text { increase }\end{array}$ \\
\hline $\begin{array}{l}\text { W.L. } \\
\text { A.L. } \\
\text { W.S. } \\
\text { T.McW. }\end{array}$ & $\begin{array}{l}13 \cdot 6 \\
12 \cdot 8 \\
11 \cdot 8 \\
12 \cdot 4\end{array}$ & $\begin{array}{l}2 \cdot 6 \\
2 \cdot 0 \\
1 \cdot 0 \\
1 \cdot 2\end{array}$ & $\begin{array}{l}32 \\
32 \\
30 \\
32\end{array}$ & $\begin{array}{l}\overline{-} \\
\overline{-} \\
-\end{array}$ & $\begin{array}{l}0.385 \\
0.38 \\
0.375 \\
0.355\end{array}$ & $\begin{array}{l}- \\
-\end{array}$ & $\begin{array}{l}- \\
-\end{array}$ & $\begin{array}{l}\overline{-} \\
\overline{-}\end{array}$ & $\begin{array}{l}\overline{-} \\
-\end{array}$ & $\begin{array}{l}1 \cdot 3 \\
<1 \\
1 \cdot 5 \\
1 \cdot 5\end{array}$ & $\begin{array}{l}6 \cdot 2 \\
6 \cdot 6 \\
5 \cdot 1 \\
6 \cdot 6\end{array}$ \\
\hline
\end{tabular}

${ }^{1}$ Result received from Royal Perth Hospital, Western Australia, through the kindness of Dr. M. Traub.

A tentative diagnosis of thalassaemia minor, with iron deficiency, was made. The former diagnosis was confirmed by the presence of $6.2 \%$ haemoglobin $A_{2}$ and haemoglobin $\mathrm{F}$ was found at a concentration of $1 \cdot 2 \%$.

Unfortunately it was not possible to trace any blood relations of this patient as she had been adopted in childhood. Her mother was known to be Scottish and her father is of unknown ancestry.

CASE 2 E.McC., a woman 25 years old, presented in 1959 for investigation of a hypochromic anaemia which had been unresponsive to repeated courses of iron therapy. Examination was negative apart from moderate pallor of the mucous membranes. The blood count is recorded in

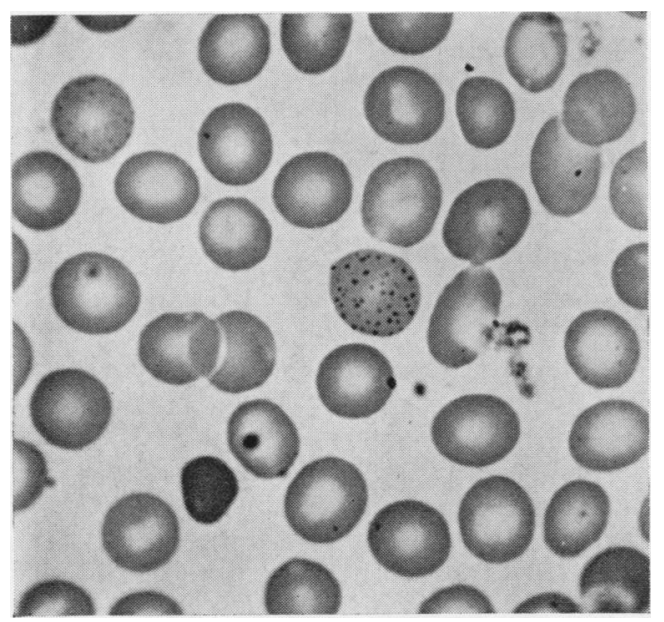

FIG. 2. Blood film E.McC. Punctate basophilia in two cells. Leishman $\times 1,000$. the Table; prominent punctate basophilia was seen in the film (Fig. 2). Red cell survival was normal ( $\mathrm{T} \frac{1}{2}$ of ${ }^{51} \mathrm{Cr}=$ 24 days).

A diagnosis of thalassaemia minor was then suspected and confirmed by finding haemoglobin $\mathrm{A}_{2}$ at a concentration of $7.4 \%$ in the red cells. The concentration of haemoglobin $\mathrm{F}$ was $1.9 \%$.

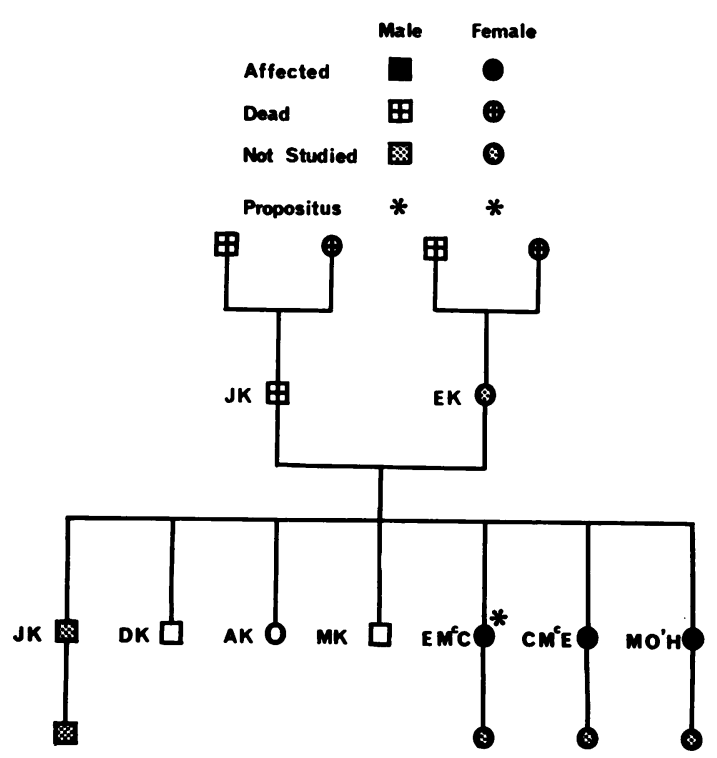

Family tree I E.McC. (case 2)

The patient's family (see family tree I) was investigated and the findings are shown in the Table. Two sisters had definite evidence of the thalassaemia 
trait. The mother is of southern Irish and the father was of Scottish stock, and in neither was there any evidence of other foreign ancestry. The father died at the age of 54 years in Stobhill Hospital, Glasgow. The diagnosis was given as chronic alcoholism, anaemia, cardiac failure and vitamin deficiencies. The anaemia was described as normoblastic with a haemoglobin concentration of $9 \cdot 1 \mathrm{~g}$. per $100 \mathrm{ml}$. and was unresponsive to intravenous iron therapy. The original blood film and marrow are not available for scrutiny. It seems probable that the father carried the thalassaemia gene.

CASE 3 J.G., a woman 26 years old, presented in 1961 with symptoms of anaemia. She had received courses of both oral and intramuscular iron therapy for a hypochromic anaemia, without benefit. The blood count is recorded in the Table; the film showed anisocytosis, poikilocytosis, and hypochromia. Haemoglobin $\mathbf{A}_{2}$ was $4.4 \%$; the amount of foetal haemoglobin was less than $2 \%$.

The father (J. J.) of this patient was found to have a bronchial carcinoma. His blood count shown in the Table and the film showed anisocytosis, poikilocytosis, and hypochromia. Haemoglobin $\mathrm{A}_{2}$ concentration was raised to $5.8 \%$. Haemoglobin $F$ was present in a concentration of less than $2 \%$.

The mother's blood was found to be normal in all respects; the patient has three brothers and one sister (see family tree II). Haematological findings in

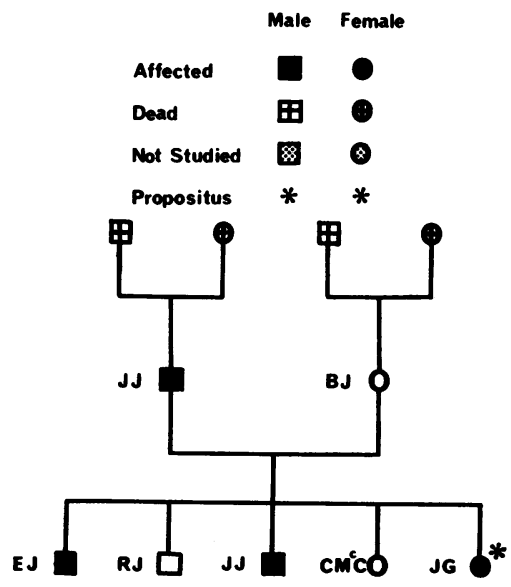

Family tree II J. G. (case 3)

the sister and one brother were normal, but two brothers had evidence of the thalassaemia trait. These results are shown in the Table. The father is Scottish and the mother southern Irish.

CASE 4 M.McT., a woman 63 years old, presented in 1958 with thyrotoxicosis and anaemia. The blood findings are recorded in the Table; the film showed anisocytosis, 을 poikilocytosis, and hypochromia of the red cells, and $\Rightarrow$ target cells were not a feature (Fig. 3). Iron therapy by both the oral and intramuscular routes failed to correct $\bar{C}$ the anaemia. Haemoglobin $\mathrm{A}_{2}$ was found to be increased흐 to $5.2 \%$, and haemoglobin $\mathrm{F}$ was also present in an $\overline{\bar{S}}$

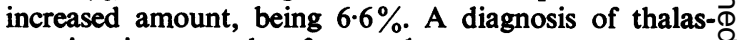
saemia minor was therefore made.

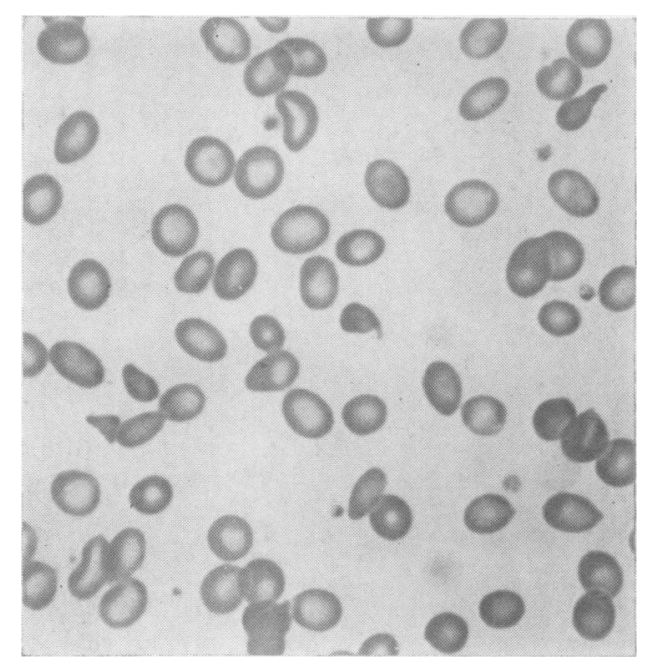

FIG. 3. Blood film M.McT. A hypochromic anaemia as in simple iron-deficiency. Leishman $\times 650$.

The patient is the sole surviving member of her $\overrightarrow{0}$ generation. She had 12 siblings, seven of whom died 3 in infancy. There is foreign ancestry on both the? paternal and maternal sides of her family (see family? tree III). Eleven of the family descendants were investigated including the propositus, and eight:showed evidence of thalassaemia (see Table). Only 3 the propositus, and T.McW. have symptoms of tiredness and dyspnoea.

\section{DISCUSSION}

Abnormalities conforming with those described in $\beta$-chain thalassaemia (Dormandy, Lock, and Leh- $\sigma$ mann, 1961) have been found in five members of four $N$ Scottish families. The forebears of cases 1, 2, and 3 N appear to be Scottish or Irish, although othero remote foreign ancestry cannot be excluded especially in case 1 (C.R.) who is an adopted child. The condition is probably commoner in Britain than? was once thought, and it seems likely that, as a result 0 of the recent development of more specific diagnostico methods, further examples will be detected among patients with refractory hypochromic anaemia. It $\vec{D}$ would be interesting to know the incidence of thalas- 


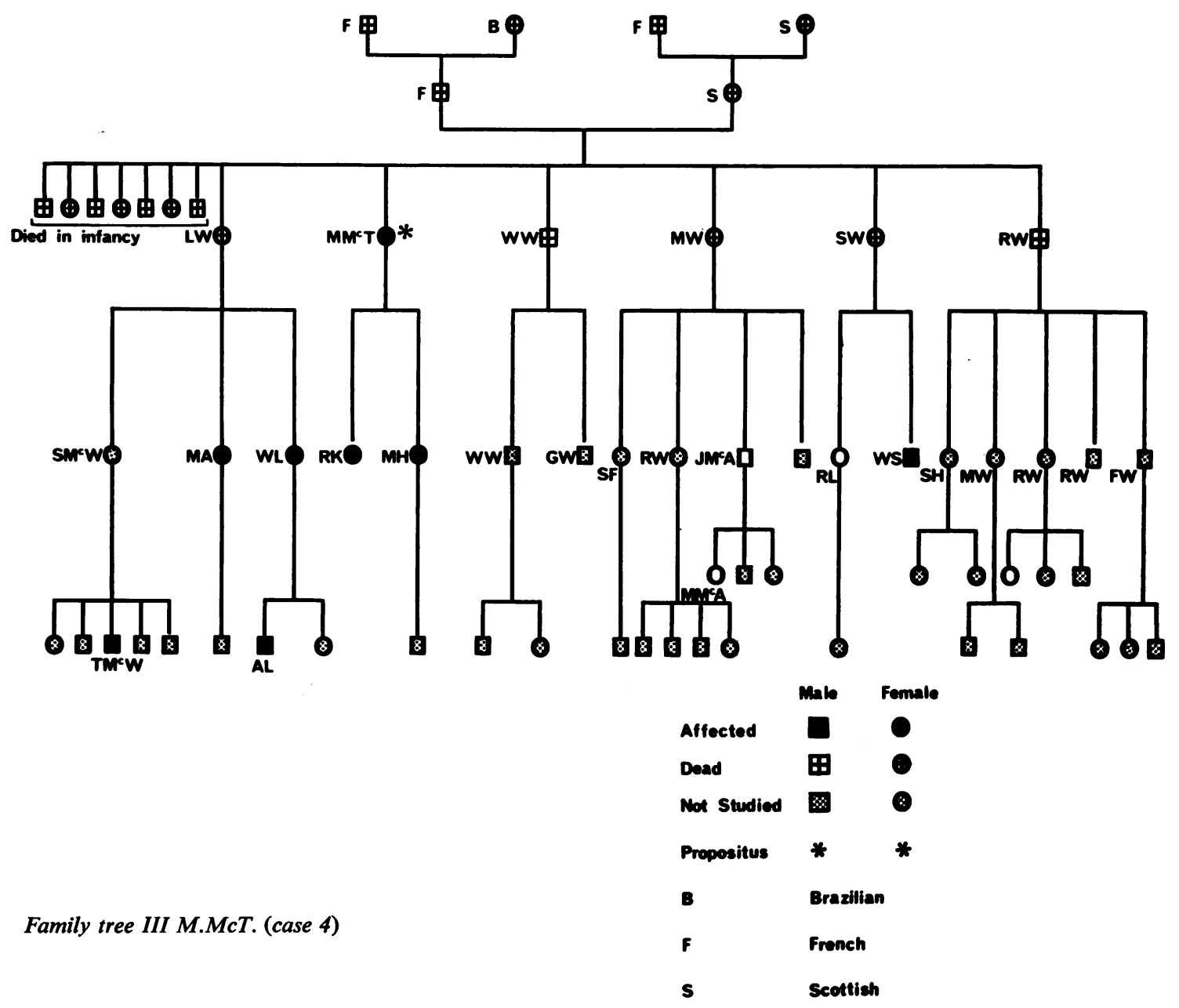

saemia in southern Ireland, in view of the centuriesold trading association with Spain.

The four propositi presented with hypochromic anaemia which had been resistant to oral and intramuscular iron. All were noted to have undue anisocytosis and poikilocytosis of the red cells. Target cells and inclusion bodies were also sometimes present while the characteristic increase in resistance to lysis by hypotonic saline was noted in all. Similar abnormalities were found in blood relatives. The diagnosis was confirmed by finding increased amounts of haemoglobin $A_{2}$, the concentration of which varied substantially in different members of the same family.

It is usual in thalassaemia minor to find a normal or raised level of serum iron but case 1 (C.R.) had a concomitant iron deficiency with a low serum iron level and stainable iron was not present in the marrow. Callender et al. (1961) also found evidence of iron deficiency in two of their 25 cases. However, iron deficiency is an uncommon finding with thalassaemia minor and iron therapy is useless and may even be harmful (Dacie, 1960).

In three instances marrow smears stained for iron showed sideroblasts but not in obviously increased numbers. When these preparations were decolourized and restained by the P.A.S. method, the erythroblasts showed a negative reaction. It had been hoped that one or perhaps both of these methods might be of taxonomic value in the differentiation of refractory anaemia of hypochromic type, but further experience would obviously be necessary for a final assessment.

Only rarely is a patient with refractory hypochromic anaemia likely to prove to have thalassaemia minor. In most instances, therefore, it will clearly be unrewarding to proceed with a full investigation of this possibility without the preliminary use of some 


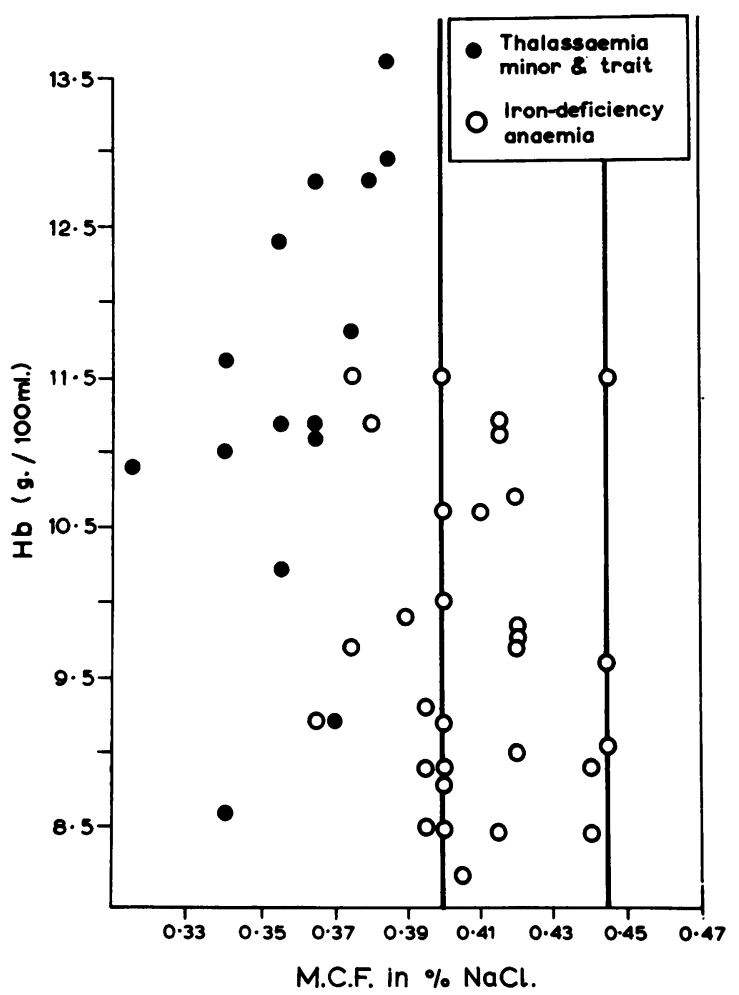

FIG. 4. Comparison of the mean corpuscular fragility (M.C.F.) in the thalassaemia trait with the M.C.F. in irondeficiency anaemia. Applying the ' $t$ ' test to these results, the differences in the M.C.F.s in these two conditions are statistically significant at the $0.1 \%$ level $(\mathrm{P}<0.001)$. The normal range $(0.4$ to $0.445 \% \mathrm{NaCl})$ is indicated by the dark vertical lines.

form of simple screening test. Many have emphasized the consistent way in which, as was seen in our own subjects, the osmotic resistance is increased even in mild types of thalassaemia (e.g., Valentine and Neel, 1944; Mooney, 1952), but it is also well known that increased osmotic resistance is found in simple iron-deficiency anaemia. However, accounts of actual mean corpuscular fragility determinations in both iron deficiency (Cassells, 1938) and thalassaemia are few and it seemed worthwhile to see whether the determination of this single index might serve as a suitable screening test.

We therefore compared the results for mean corpuscular fragility which we had obtained with those in 30 patients with iron-deficiency anaemia, whose haemoglobin fell within the range 8 to $11 \cdot \frac{\text { है }}{5}$ g./100 ml., comparable to that of our cases of: thalassaemia. In each case of iron deficiency the possibility of thalassaemia minor was excluded by the presence of normal amounts of haemoglobin $A_{\mathbb{D}} \frac{-}{D}$ on electrophoresis, or of a satisfactory response ton iron. The results are presented in Figure 4. In each of the 15 cases of thalassaemia the mean corpuscula fragility indicates increased osmotic resistances whereas in only eight of the 30 cases of iron? deficiency anaemia was a similar, and then usually less pronounced, effect observed. If, therefore, w patient has a refractory hypochromic anaemia with normal mean corpuscular fragility it would seem. that thalassaemia minor may be excluded from the differential diagnosis, but if the mean corpusculat fragility indicates increased resistance then furthefo investigation of the possibility of thalassaemia minoo is justified.

It is noteworthy that of the 16 individuals affected $\vec{z}$ only the four propositi and T.McW. (see Table) had symptoms. The others were entirely symptom-free and may be regarded as carriers of the trait illustrating the variable penetrance of the gene. This is in accord. with the findings of Callender et al. (1961), althougk several of the cases of Israëls et al. (1955) in \& Scottish family had severe symptoms from childhood? We are grateful to Professor L. J. Davis, Professor E. Ms McGirr, Professor E. J. Wayne, Dr. A. H. Imrie, and Dro Grace Ritchie for permission to publish these cases? which were investigated under their care. We thank Dr. $H_{\Omega}^{\mathbb{D}}$ Lehmann who estimated some of the initial haemoglobir $A_{2}$ and haemoglobin $F$ levels.

\section{REFERENCES}

Callender, S. T., Mallet, B. J., and Lehmann, H. (1961). Brit. Haemat. , 7, 1.

Cassells, D. A. K. (1938). J. Path. Bact., 47, 603.

Dacie, J. V. (1956). Practical Haematology, 2nd ed. Churchill, London (1960). The Haemolytic Anaemias, Congenital and Acquired, 2n⿺ ed. Part I, p. 215. Churchill, London.

Dormandy, K. M., Lock, S. P., and Lehmann, H. (1961). Brit. med. J. $1,1582$.

Havard, C. W. H. , Lehmann, H., and Scott, R. B. (1958). Ibid. , 1, 3040 Hutchison, H. E., Pinkerton, P. H. , Cassidy, P., and Aiton, M. (1963)? Scot. med.J., 8, 149.

Israëls, L. G. , Suderman, H. J., and Hoogstraten, J. (1955). Lancet, 2 ㄱㅡㅡ 1318.

Israëls, M. C. G., and Turner, R. L. (1955). Ibid., 2, 1363.

Josse, S. E. (1962). Brit. med. J., 1, 528.

McFarland, W., and Pearson, H. A. (1960). Ann. intern. Med., 53 . 510.

Mollison, P. L., and Veall, N. (1955). Brit. J. Haemat., 1, 62. Mooney, F. S. (1952). J. clin. Path., 5, 154.

Singer, K., Chernoff, A. I., and Singer, L. (1951). Blood, 6, 413. Valentine, W. N. , and Neel, J. V. (1944). Arch. intern. Med., 74, 1850

Vella, F., and Ibrahim, S. A. (1961). Nature (Lond.), 191, 822.

Went, L. N., and McIver, J. E. (1961). Blood, 17, 166. 